\title{
Pharmacokinetic and pharmacodynamic integration for optimal dosage of cefquinome against Streptococcus equi subsp. equi in foals
}

\author{
Dong-Ha Lee ${ }^{1}$, Biruk Tesfaye Birhanu', Eon-Bee Lee', Seung-Jin Lee ${ }^{2}$, Naila Boby', Yong-Soo Park ${ }^{3^{*}}$ \\ and Seung-Chun Park ${ }^{*}$ (1)
}

\begin{abstract}
Cefquinome is administered in horses for the treatment of respiratory infection caused by Streptococcus equi subsp. zooepidemicus, and septicemia caused by Escherichia coli. However, there have been no attempts to use cefquinome against Streptococcus equi subsp. equi (S. equi), the causative agent of strangles. Hence the objective of this study was to calculate an optimal dosage of cefquinome against $S$. equi based on pharmacokinetics and pharmacodynamics integration. Cefquinome $(1.0 \mathrm{mg} / \mathrm{kg})$ was administered by intravenous and intramuscular routes to six healthy thoroughbred foals. Serum cefquinome concentrations were determined by high-performance liquid chromatography. The in vitro and ex vivo antibacterial activity were determined from minimum inhibitory concentrations (MIC) and bacterial killing curves. The optimal dosage was calculated from the integration of pharmacokinetic parameters and area under the curve $\left(\mathrm{AUC}_{24 \mathrm{~h}} / \mathrm{MIC}\right)$ values. Total body clearance and volume of distribution of cefquinome after intravenous administration were $0.06 \mathrm{~L} / \mathrm{h} / \mathrm{kg}$ and $0.09 \mathrm{~L} / \mathrm{kg}$, respectively. Following intramuscular administration, a maximum concentration of $0.73 \mu \mathrm{g} / \mathrm{mL}$ at $1.52 \mathrm{~h}\left(T_{\max }\right)$ and a systemic bioavailability of $37.45 \%$ were observed. The MIC of cefquinome against S. equi was $0.016 \mu \mathrm{g} / \mathrm{mL}$. The ex vivo $\mathrm{AUC}_{24 \mathrm{~h}} / \mathrm{MIC}$ values representing bacteriostatic, and bactericidal activity were 113.11 , and $143.14 \mathrm{~h}$, respectively. Whereas the $\% \mathrm{~T}>\mathrm{MIC}$ for bactericidal activity was 153.34\%. In conclusion, based on $\mathrm{AUC}_{24 \mathrm{~h}} / \mathrm{MIC}$ values and pharmacokinetic parameters, cefquinome when administered by intramuscularly at a dosage of $0.53 \mathrm{mg} / \mathrm{kg}$ every $24 \mathrm{~h}$, would be effective against infection caused by $\mathrm{S}$. equi in foals. Further studies may be necessary to confirm its therapeutic efficacy in a clinical environment.
\end{abstract}

Keywords: cefquinome, Streptococcus equi subsp. equi, antibacterial activity, PK/PD integration, optimal dosage

\section{Introduction}

Cefquinome is a fourth-generation amino-thiazolyl cephalosporin used solely in veterinary medicine [1-3]. The chemical modifications of the basic cephalosporin structure provide cefquinome's zwitterionic property that

\footnotetext{
*Correspondence: parksch@knu.ac.kr; parksch@knu.ac.kr

${ }^{1}$ Laboratory of Veterinary Pharmacokinetics and Pharmacodynamics,

College of Veterinary Medicine, Kyungpook National University, Bukgu, Daegu 41566, Republic of Korea

${ }^{3}$ Department of Equine Industry, Korea National College of Agriculture and Fisheries, Jeonju 54874, Republic of Korea

Full list of author information is available at the end of the article
}

facilitates its rapid penetration across Gram-negative outer membranes, including the porins of the bacterial cell wall and broaden the antimicrobial activity spectrum compared with previous generation cephalosporins $[2,4$, 5]. Cefquinome has been widely used for treating various infections in cattle and pigs [3]. In horses, cefquinome has been used for the treatment of respiratory tract diseases caused by Streptococcus equi subsp. zooepidemicus, and foal septicemia caused by Escherichia coli, with a recommended dose regimen of $1 \mathrm{mg} / \mathrm{kg}$. However, there have been no prior reports using cefquinome as a treatment for strangles in horses.

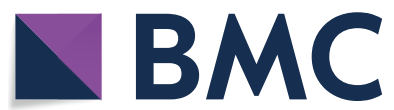

c The Author(s) 2020. This article is licensed under a Creative Commons Attribution 4.0 International License, which permits use, sharing, adaptation, distribution and reproduction in any medium or format, as long as you give appropriate credit to the original author(s) and the source, provide a link to the Creative Commons licence, and indicate if changes were made. The images or other third party material in this article are included in the article's Creative Commons licence, unless indicated otherwise in a credit line to the material. If material is not included in the article's Creative Commons licence and your intended use is not permitted by statutory regulation or exceeds the permitted use, you will need to obtain permission directly from the copyright holder. To view a copy of this licence, visit http://creativeco mmons.org/licenses/by/4.0/. The Creative Commons Public Domain Dedication waiver (http://creativecommons.org/publicdomain/ zero/1.0/) applies to the data made available in this article, unless otherwise stated in a credit line to the data. 
Strangles (equine distemper) is a highly contagious upper respiratory tract disease of equines caused by Streptococcus equi subsp. equi (S. equi), which is a Gram-positive bacterium, belongs to $\beta$-hemolytic, Lancefield group C streptococci [6]. Strangles affects horses of all ages but is most common in weanling foals or yearlings, whose clinical symptoms are more severe. The penicillins have been considered the drug of choice for the treatment of strangles [7]. Besides, ceftiofur, ceftriaxone, cefotaxime and cefquinome have also shown to have high efficacy in vitro against strains of $S$. equi $[8,9]$. Potentially, cefquinome would have therapeutic effects on infections caused by these strains. However, experimental evidence evaluating the effects of cefquinome against $S$. equi are limited, and there are no reported studies about using cefquinome in clinical circumstances for the treatment of strangles.

The pharmacokinetics (PK) of cefquinome have been studied in horses and various animals, including sheep, buffalo calves, camels, goats and laboratory animals [5, 10-15]. The optimal dose range of cefquinome has been suggested to be $1-10 \mathrm{mg} / \mathrm{kg}$ based on the minimum inhibitory concentration (MIC) and the PK parameters. However, designing the dosage regimens based on PK profiles only, and MIC as a sole parameter of the pharmacodynamic (PD) response, is insufficient because of the complex relationships between the concentration of antibiotics, bacterial susceptibility and the PD inhibitory effects against bacteria [16]. In order to bridge the gap, integration of PK parameters and multiple PD models, such as the maximum effect $\left(E_{\max }\right)$ model, has been utilized to predict optimal dosages, which have been known to improve the clinical response to therapy and reduce the antimicrobial resistance [16]. Although studies regarding the integration of PK/PD of cefquinome have been conducted previously in some animals, there have been no previous attempts to suggest optimized dosage of cefquinome against $S$. equi in horses using PK/PD integration $[17,18]$.

Therefore, the objectives of this study were (1) to determine the concentrations of cefquinome in serum and PK parameters following intravenous (IV) and intramuscular (IM) administration at a dose of $1 \mathrm{mg}$ / $\mathrm{kg}$ in horses using high-performance liquid chromatography (HPLC); (2) to provide the degree of serum protein binding; (3) to estimate the in vitro and ex vivo antibacterial activity of cefquinome against $S$. equi; and (4) to calculate the optimal dosage regimen for the infections caused by $S$. equi based on cefquinome PK/ PD parameters.

\section{Material and methods}

\section{Drugs and reagents}

Cefquinome sulphate was purchased from Sigma (St. Louis, MO, USA). All reagents used for analysis in this experiment were HPLC or analytical grade and obtained from commercial sources: acetonitrile $(\mathrm{ACN})$ and methanol (MeOH) (Duksan, Ansan, Korea), High Performance Liquid Chromatography (HPLC) grade water (Fisher ChemAlert Guide, Marietta, OH, USA) and trifluoroacetic acid (TFA; Sigma). Cefquinome sulphate (Cefa4 inj ${ }^{\circledR}$ ) for IV and IM administration was purchased from Shinil Biogen Co., LTD. (Ayang, South Korea).

\section{Animals and experimental design}

The experiments were performed with six healthy thoroughbred horses (age, 6 months to 1 year), weighed $186 \pm 23.5 \mathrm{~kg}$, from the Korea National College of Agriculture and Fisheries. The horses were acclimatized to the environment for three weeks before the start of the experiment. The animals were housed in shaded and ventilated individual stalls, and hay and water were provided ad libitum.

Prior to the experiment, a clinical exam including physical examination, heart rate, and rectal temperature was checked that the horses were healthy. In addition, animals did not receive any antibiotic treatment for one month prior to the experiment. A two-phase cross-over design was performed in six horses. In period one, three horses of the first group received $1 \mathrm{mg} / \mathrm{kg}$ (total volume of $2 \mathrm{~mL}$ per $50 \mathrm{~kg}$ ) of cefquinome by IV administration through the jugular vein, and the other group received the same dose of cefquinome by IM administration in the neck region between the scapula, the cervical spine, and nuchal ligament. Two weeks of wash-out ensued to ensure complete excretion of the drug from the bodies. In the second phase, the route of administration reversed, and the jugular veins used for administration of the drug and sample collection were different.

All research protocols and animal experiments in this study were reviewed and approved by the Institutional Animal Care and Use Committee (IACUC) in Gyeongsangbuk-do, Republic of Korea (Gyeongbuk IACUC-81).

\section{Sample collection and preparation}

Six milliliters of blood samples were collected from the left jugular vein into 10 -mL plain tubes using direct stick method. A total of 10 blood samples per horse were collected before $(0 \mathrm{~h})$ and at $0.25,0.5,0.75,1,2,4,8,12$ and $24 \mathrm{~h}$ after the drug administration as described previously $[19,20]$. The blood samples were kept at room temperature, and clot retraction was allowed. Serum samples were separated by centrifugation at $5,000 \times g$ at $4{ }^{\circ} \mathrm{C}$ for 
$20 \mathrm{~min}$, and then $3 \mathrm{~mL}$ of supernatant serum was separated and stored at $-70^{\circ} \mathrm{C}$ until analysis.

\section{Sample treatment for HPLC analytical method}

Aliquots $(200 \mu \mathrm{L})$ of the serum sample were pipetted into 1.5-mL eppendorf tubes. Subsequently, $400 \mu \mathrm{L}$ of $\mathrm{MeOH}$ was added to the aliquots for deproteinization. The samples were agitated for $10 \mathrm{~s}$ using a vortex mixer and centrifuged at 5,000 $\mathrm{g} g$ for $10 \mathrm{~min}$. Then, the supernatant of the extract was filtered through a $0.45-\mu \mathrm{m}$ PTFE syringe filter (Advantec, Japan) and transferred into a fresh autosampler vial. Twenty microliters of supernatant were injected into the HPLC system.

\section{HPLC instrumentation and analysis conditions}

An HPLC Agilent Technologies 1100 series (Santa Clara, CA, USA) Series system comprising a reversephase Eclipse Plus $\mathrm{C}_{18}$ column (particle size, $5 \mu \mathrm{m}$; $4.6 \times 250 \mathrm{~mm}$ ), a quaternary HPLC pump, an autosampler and a UV detector was used to measure the cefquinome concentration in serum samples. The column compartment temperature was kept at $40{ }^{\circ} \mathrm{C}$. The mobile phase consisted of $\mathrm{ACN}$ and water containing $0.1 \%$ TFA.

Table 1 Mobile phase conditions for high-performance liquid chromatography in vitro analysis of cefquinome

\begin{tabular}{llll}
\hline Time (min) & Flow rate (mL/min) & A (\%) & B (\%) \\
\hline 0 & 1.1 & 90 & 10 \\
7 & 1.1 & 50 & 50 \\
10 & 1.1 & 50 & 50 \\
11 & 1.1 & 90 & 10 \\
15 & 1.1 & 90 & 10 \\
\hline
\end{tabular}

$\mathrm{A}$ is acetonitrile, and $\mathrm{B}$ is water containing $0.1 \%$ trifluoroacetic acid
The concentrations of cefquinome were determined using the method described by Uney et al. with minor modifications [21]. The method used a binary gradient condition with water containing $0.1 \%$ TFA as mobile phase $\mathrm{A}$ and $\mathrm{ACN}$ as mobile phase $\mathrm{B}$. The time program of the gradient is presented in Table 1 . The flow rate was $1.1 \mathrm{~mL} / \mathrm{min}$, and the injection volume was $20 \mu \mathrm{L}$. The detection was measured using a UV detector set at $268 \mathrm{~nm}$. The Agilent Chemstation software program (Agilent Technologies) was utilized to analyze the data and control the HPLC system.

\section{Validation of HPLC analytical method}

A standard solution of cefquinome was prepared by the direct weighing of the standard substance with dissolution in sterile distilled HPLC grade water and appropriate buffer. The concentration of the standard stock solution was $1 \mathrm{mg} / \mathrm{mL}$, and the stock solution was stored at $-20{ }^{\circ} \mathrm{C}$. The standard stock solution was diluted quantitatively to obtain concentrations of $0.8,1.6,3.2,6.25$, 12.5 and $25 \mu \mathrm{g} / \mathrm{mL}$. After the stock solution had dissolved, blank serum samples from six horses that did not receive antibiotics were used to prepare the spiked samples at concentrations of 0.08, 0.16, 0.32, 0.625, 1.25 and $2.5 \mu \mathrm{g} / \mathrm{mL}$, for calibration curves. Blank, spiked and pooled serum samples were analyzed to check for chromatographic interference peaks during the elution phase of cefquinome. Representative chromatograms of a blank serum, a spiked serum sample with $10 \mu \mathrm{g} / \mathrm{mL}$ of cefquinome, and a pooled serum sample collected at $15 \mathrm{~min}$ after IV administration are shown in Figure 1.

Linearity was determined in triplicate at different days by injections of six spiked serum samples ranging in concentration from 0.08 to $2.5 \mu \mathrm{g} / \mathrm{mL}$. The calibration curve was represented by the following equation: $y=a x \pm b$,

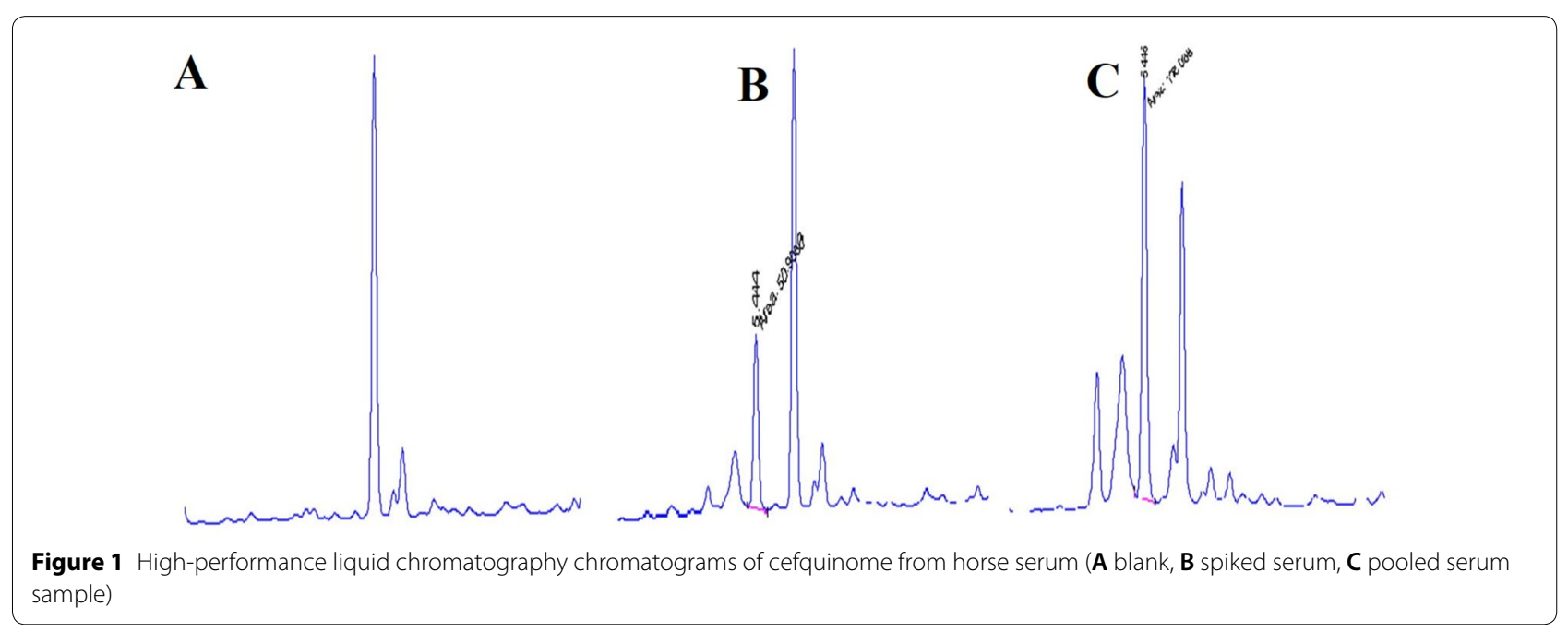


where $y$ is peak area; $x$ is concentration $(\mu \mathrm{g} / \mathrm{mL})$. The detection and quantification limits were determined by the analysis of spiked serum samples. The limit of detection (LOD) was defined as the minimum level (lowest calibration standard) at which cefquinome was detected from background noise, but not quantifiable. The limit of quantification (LOQ) was defined as the lowest concentration of cefquinome analytes that could be measured with acceptable precision and accuracy [22].

Blank serum samples were spiked with cefquinome at a concentration range of $0.1-10 \mu \mathrm{g} / \mathrm{mL}$ and deproteinated with $\mathrm{MeOH}$. After extraction of the analytes from the matrix and injection into the HPLC system, the recovery was determined by comparing the resulting peak areas with those of standard solutions with corresponding concentrations. Repeatability was studied for three injections of spiked serum samples at six different concentrations on the same day [22].

\section{Serum protein binding}

The differences in the inhibition zone diameter between buffer solutions and blank serum samples were used to calculate the in vitro serum protein binding tendency of cefquinome, using the following equation described by Craig and Suh [23].

$$
\text { Protein binding }(\%)=\frac{\text { Zone of inhibition (buffer) }- \text { Zone of inhibition }(\text { serum })}{\text { Zone of inhibition (buffer) }} \times 100
$$

The serum protein binding percentage of cefquinome at a concentration range of $0.16-20 \mu \mathrm{g} / \mathrm{mL}$ was estimated and presented in Additional file 1.

\section{Pharmacokinetics analysis}

A computerized curve-stripping software program (WinNonlin, Certara, NJ, USA) was used to analyze the time versus serum concentration data after IV and IM administration of cefquinome for both one and two- compartmental models. The best-fitting model was chosen by the minimum Akaike's information criterion estimation [24]. Normal (non-weighted) data were used for the analysis after comparing the distribution of the error around the lower and higher concentrations curve.

As a result, a biexponential equation was fitted to the serum concentration curves of cefquinome after a single IV administration. The PK parameters were calculated from the following equation: $C_{\mathrm{IV}}(t)=A e^{(-\alpha t)}+B e^{(-\beta t)}$. $C_{\mathrm{IV}}(t)$ is the concentration in serum at time $(t)$ after IV administration; $A e^{(-\alpha \mathrm{t})}$ represents the distribution phase and $B e^{(-\beta t)}$ denotes the elimination phase. Based on this equation, the following variables were obtained: zero-time serum concentration intercepts of biphasic
IV disposition curves $(A$ and $B)$; distribution and elimination rate constant $(\alpha$ and $\beta)$; half-life of distribution and elimination ( $\alpha \_$HL and $\left.\beta \_H L\right)$; area under the curve (AUC); area under the first moment curve (AUMC); firstorder transfer rate constants for drug distribution from the central compartment to the peripheral compartment and from the peripheral compartment to the central compartment ( $K_{12}$ and $K_{21}$, respectively); mean residence time (MRT); volume of distribution at steady-state $\left(\mathrm{Vd}_{\mathrm{ss}}\right)$; total body clearance (CLB).

After a single IM administration of cefquinome, a mono-exponential equation was applied to the serum concentration curves of cefquinome. The PK parameters were determined from the following equation: $C_{\mathrm{IM}}(t)=A \times\left(\mathrm{e}^{-K 10 t}-\mathrm{e}^{-K 01 t}\right) . C_{\mathrm{IM}}(t)$ is the concentration in serum at the time $(t)$ after IM administration; $A$ is $D \times K_{01} / V \times\left(K_{01}-K_{10}\right)$, where $D$ is dose; $V$ is the volume of distribution; $K_{01}$ and $K_{10}$ is first-order absorption and elimination rate constant, respectively. Based on this equation, the PK parameters, including $K_{01}$ and $K_{10}$, the half-life of absorption and elimination $\left(K_{01}+\mathrm{HL}\right.$ and $\left.K_{10} \mathrm{HL}\right)$, maximum serum concentration $\left(C_{\max }\right)$, the time required to achieve $C_{\max }\left(T_{\max }\right)$ and the AUC were calculated from the equation. Bioavailability $(F)$ was calculated from the following equation: $F(\%)=\mathrm{AUC}_{\mathrm{IM}} / \mathrm{AUC}$
IV $\times 100$. All data obtained from the WinNonlin program was expressed as the mean \pm standard deviation (SD).

\section{Determination of MIC}

The strains S. equi (ATCC 39506) and E. coli (ATCC 25922), as a quality control microorganism, were used. Both microorganisms were purchased from the Korea Culture Centre of Microorganisms (KCCM). In order to determine the MIC for cefquinome, broth microdilution methods were performed, as outlined by the Clinical Laboratory and Standard Institute (CLSI) [25]. The bacteria cultures were grown freshly from beads stock stored at $-70{ }^{\circ} \mathrm{C}$, on tryptic soy blood (TSB) agar for $S$. equi and Luria-Bertani (LB) agar for E. coli. The standard inoculum was prepared by direct suspension in TSB and $\mathrm{LB}$, respectively, and adjusted with sterile saline until the turbidity matched a $0.5 \mathrm{McF}$ arland standard. The exact inoculum size was confirmed later via colony counts [22]. The bacterial cultures were diluted to approximately $2 \times 10^{6} \mathrm{cfu} / \mathrm{mL}$, and $100 \mu \mathrm{L}$ of diluted bacterial suspension was inoculated into 96-well microplates, which contained serially-diluted cefquinome ranging from 0.001 to $256 \mu \mathrm{g} / \mathrm{mL}$, and also, inoculated into drug-free control 
wells. The MIC was defined as the lowest concentration of drug at which no visible growth was determined visually by examination of the plates after $24 \mathrm{~h}$ of incubation at $37^{\circ} \mathrm{C}$. In addition, the optical density $\left(\mathrm{OD}_{600}\right)$ was determined using a VersaMax ${ }^{\circledR}$ microplate reader (Molecular Devices, Sunnyvale, CA, USA).

\section{Ex vivo bacterial killing curves}

Standard inoculums were prepared, as described above, for MIC determination. The serum samples collected from horses prior to $(0 \mathrm{~h})$ and at $0.5,1,2,4,8,12$ and $24 \mathrm{~h}$ after IM administration of cefquinome were used to determine the ex vivo bacterial killing curves against $S$. equi. To $1 \mathrm{~mL}$ of each serum sample, $10 \mu \mathrm{L}$ of stationary phase bacterial culture was added to give a final concentration of approximately $2 \times 10^{6} \mathrm{cfu} / \mathrm{mL}$ and incubated. Aliquots $(50 \mu \mathrm{L})$ were withdrawn from each culture tube at $1,2,4,8,12$ and $24 \mathrm{~h}$ after incubation, and transferred for tenfold serial dilutions in $0.1 \%$ agar saline. Fifty microlitres of the suspension was then dropped onto quadrants of TSB agar. Once dried, the plates were incubated at $37^{\circ} \mathrm{C}$ for $24 \mathrm{~h}$ to determine the viable counts $(\mathrm{cfu} / \mathrm{mL})$.

\section{PD analysis and PK/PD integration}

The surrogate markers of antibacterial activity, that is, the AUC-to-MIC ratio (AUIC) and the duration during which the serum drug concentration exceeds the MIC (\%T>MIC), were determined using in vitro PK parameters, MIC values and ex vivo PD parameters obtained from IV and IM administration of cefquinome. The inhibitory sigmoid $E_{\max }$ model, using the WinNonlin software program, was applied to calculate the ex vivo AUC/MIC ratio for the determination of the bacteriostatic $(E=0)$, bactericidal $(E=-3)$ and bacterial elimination $(E=-4)$ activities. As described previously by Aliabadi and Lees, the $\log _{10}$ difference between the bacterial count $(\mathrm{cfu} / \mathrm{mL})$ of the initial inoculum and the bacterial count at $24 \mathrm{~h}$ after incubation was fitted against the ex vivo $\mathrm{AUC}_{24 \mathrm{~h}} / \mathrm{MIC}$ [26]. The values of ex vivo $\mathrm{AUC}_{24 \mathrm{~h}} /$ MIC were estimated by multiplying the measured serum concentration in samples collected between 0.5 and $24 \mathrm{~h}$ following IM administration of cefquinome and then dividing this value by the MIC [22]. The PD parameters were calculated using the following equation:

$$
E=E_{0}-\frac{E_{\max } \times C_{e}^{N}}{E C_{50}^{N}+C_{e}^{N}}
$$

where $E$ is the antibacterial effect measured as the change in bacterial counts $\left(\log _{10} \mathrm{cfu} / \mathrm{mL}\right)$ in the serum sample at $24 \mathrm{~h}$ of incubation compared with the initial bacterial counts; $E_{\max }$ is the $\log _{10} \mathrm{cfu} / \mathrm{mL}$ difference in bacterial counts between 0 and $24 \mathrm{~h}$ in the drug-free serum sample; $E_{0}$ is the $\log _{10} \mathrm{cfu} / \mathrm{mL}$ difference in bacterial counts in the test sample containing cefquinome at $24 \mathrm{~h}$ of incubation when the limit of detection $(20 \mathrm{cfu} /$ $\mathrm{mL}$ ) is reached: $C_{\mathrm{e}}$ is the $\mathrm{AUC}_{24 \mathrm{~h}} / \mathrm{MIC}$ ratio in the effect compartment (serum); $E C_{50}$ is the $\mathrm{AUC}_{24 \mathrm{~h}} / \mathrm{MIC}$ of drug require to produce $50 \%$ of the maximal antibacterial effect; $N$ is the Hill coefficient, which describes the steepness of the $\mathrm{AUC}_{24 \mathrm{~h}} / \mathrm{MIC}$ effect curve.

Based on the PK parameters and $\mathrm{AUC}_{24 \mathrm{~h}} / \mathrm{MIC}$ values of the effect compartment, the optimal dosage was calculated using the following equation:

$$
\text { Dose }=\frac{\left(\mathrm{AUC}_{24 \mathrm{~h}} / \mathrm{MIC}\right) \times \mathrm{MIC} \times \text { Clearance }_{(\text {per hour })}}{F \times f u}
$$

where $\mathrm{AUC}_{24 \mathrm{~h}} / \mathrm{MIC}$ denotes the values required to achieve bacteriostatic, bactericidal and bacterial elimination activity; MIC is the minimum inhibitory concentration; $F$ is the bioavailability (see Sect. 2.8); $f u$ is the free fraction of cefquinome.

The time during which the serum concentration exceeds the MIC $(\% T>M I C)$ was calculated as follows:

$$
\% T>\mathrm{MIC}=\ln \frac{\text { Dose }}{\mathrm{Vd} \times \mathrm{MIC}} \times \frac{\mathrm{T}_{1 / 2}}{\ln 2} \times \frac{100}{\tau}
$$

where $\mathrm{ln}$ is natural logarithm; Vd is the volume of distribution; $T_{1 / 2}$ is the elimination half-life; $\tau$ is the dosing interval [27].

\section{Simulation of PK profile}

Simulation of single daily doses of cefquinome for three consecutive days was calculated using previously reported half-lives of cefquinomes in horses. The dose selection achieved the AUC and Cmax over a $24 \mathrm{~h}$ dosing interval. The average ratio of the simulated AUC/MIC corresponds to Cmax that may exceed the MIC.

\section{Statistical analysis}

The PK data was analyzed using Phoenix WinNonlin 8.1. The differences between IV and IM administration regarding the PK parameters (elimination half-life and AUC) were analyzed by a paired $t$-test, with $P<0.05$ being considered significant.

\section{Results}

Validation of HPLC analytical methods

In the HPLC analytical method, the retention time of cefquinome was $5.45 \mathrm{~min}$. No interfering peaks were detected in the blank sample during the elution phase of cefquinome. A linear relationship existed in the calibration curve between the cefquinome concentration and peak area (Additional file 2). The correlation coefficient $\left(r^{2}\right)$ was 0.9954 whereas, the equation was 
$y=19.448 x+0.9303$. The validated LOD and LOQ for cefquinome were 0.05 and $0.16 \mu \mathrm{g} / \mathrm{mL}$, respectively. The extraction recoveries were greater than $90 \%$. The accuracy and precision values are summarized in Table 2.

\section{Serum protein binding}

The protein binding rates of cefquinome in serum are shown in Additional file 1. The average in vitro serum protein binding rate over the concentration range of $0.15625-20 \mu \mathrm{g} / \mathrm{mL}$ was $3.91 \pm 0.95 \%$.

\section{Pharmacokinetics}

The time versus cefquinome concentration relationships for six horses following IV and IM administration are shown in Figure 2. The data obtained after IV administration was described by a two-compartment model. Following IM administration, the data were found to fit a one-compartment model. The calculated PK parameters following IV and IM administrations of cefquinome to six horses are presented in Tables 3 and 4, respectively.

Table 2 Accuracy and precision for Cefquinome in foal's serum

\begin{tabular}{llll}
\hline Standard & Spiked $($ mean \pm SD) & Precision & Accuracy \\
\hline 0.080 & $0.079 \pm 0.002$ & 2.5 & 99.987 \\
0.156 & $0.16 \pm 0.004$ & 2.5 & 99.981 \\
0.313 & $0.32 \pm 0.012$ & 3.9 & 99.965 \\
0.625 & $0.61 \pm 0.011$ & 1.8 & 99.969 \\
1.250 & $1.194 \pm 0.012$ & 1.0 & 99.954 \\
2.500 & $2.39 \pm 0.029$ & 1.3 & 99.913 \\
\hline
\end{tabular}

Values presented are mean \pm SD of triplicate tests
After IV administration, the elimination half-life was $2.77 \mathrm{~h}(0.40)$. Cefquinome exhibited a low volume of distribution $\left(\mathrm{Vd}_{\mathrm{ss}}\right.$ of $\left.0.09 \mathrm{~L} / \mathrm{kg}\right)$, and the CLB was $0.06 \mathrm{~L} / \mathrm{h} /$ $\mathrm{kg}$.

Following IM administration, the elimination halflife was $4.39 \mathrm{~h}(0.79)$, which was longer than that after IV administration. The maximum serum concentration $\left(C_{\max }\right)$ was $0.73 \mu \mathrm{g} / \mathrm{mL}$, which was reached at $\left(T_{\max }\right)$ $1.52 \mathrm{~h}$. whereas the AUC obtained was $5.93 \mu \mathrm{g} \cdot \mathrm{h} / \mathrm{mL}$. The mean bioavailability $(F)$ after cefquinome administration was $37.45 \%$.

\section{Pharmacodynamics}

The MIC of cefquinome was determined in broth against S. equi (ATCC 39506) and E. coli (ATCC 25922) as the quality control strain, and the MIC values were 0.016 and $0.032 \mu \mathrm{g} / \mathrm{mL}$, respectively. The serum concentration of cefquinome at $12 \mathrm{~h}$ was higher than the MIC of $S$. equi and E. coli (Figure 2).

The ex vivo antibacterial activity of cefquinome, which showed a time-dependent antibacterial activity, was determined in serum against $S$. equi at predetermined time points using serum samples collected before the administration and at $0.5,1,2,4,8,12$ and $24 \mathrm{~h}$ after IM administration. A rapid bacterial inhibition activity was observed, and no bacteria were detected (detection limit $20 \mathrm{cfu} / \mathrm{mL}$ ) after $24 \mathrm{~h}$ for serum samples collected between 1 and $8 \mathrm{~h}$ (Figure 3).

The ex vivo $\mathrm{AUC}_{24 \mathrm{~h}} / \mathrm{MIC}$ values for cefquinome in serum after IM administration of cefquinome at a dosage of $1 \mathrm{mg} / \mathrm{kg}$ are shown in Table 5. Furthermore, integration of the in vitro PK parameters, MIC and PD data

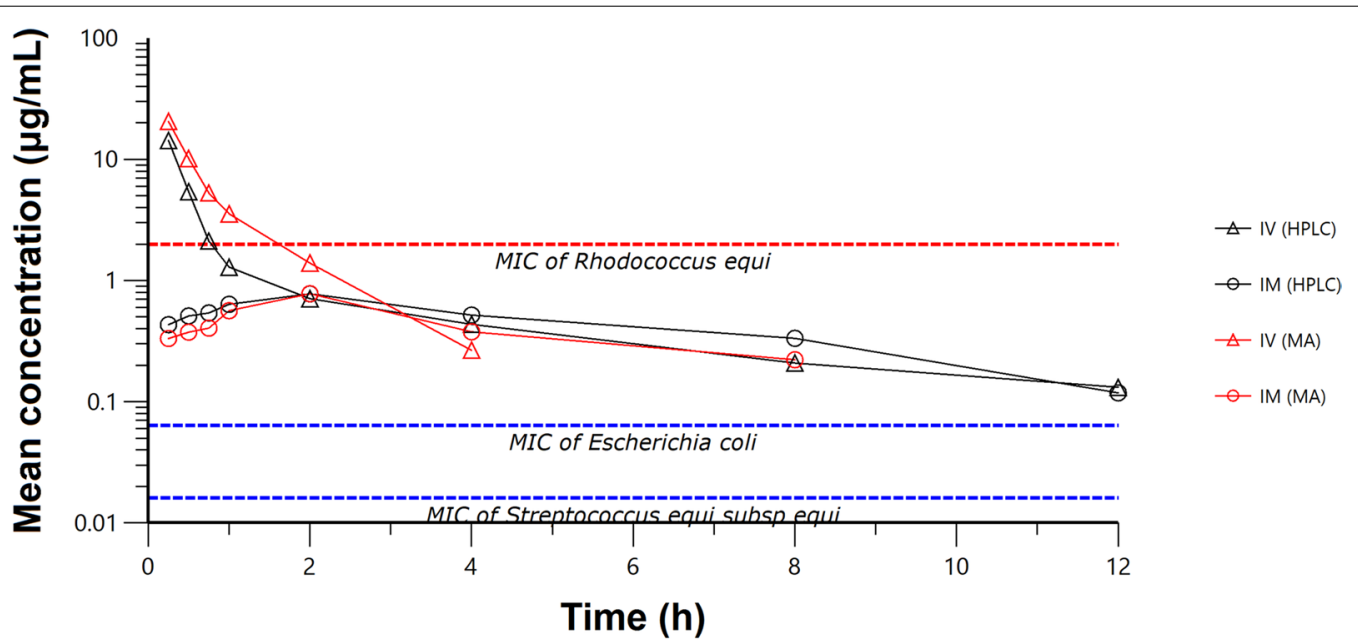

Figure 2 Semi-logarithmic graph of the time versus concentration in serum after a single IV and IM administrations of cefquinome in six horses analyzed by high-performance liquid chromatography and microbiological assay methods. The horizontal dashed line represents the MIC against Streptococcus equi subsp. equi $(0.016 \mu \mathrm{g} / \mathrm{mL})$, Escherichia coli $(0.032 \mu \mathrm{g} / \mathrm{mL})$ and Rhodococcus equi $(2 \mu \mathrm{g} / \mathrm{mL})$ 


\begin{tabular}{|c|c|c|}
\hline Parameter & Unit & Mean \\
\hline$A$ & $\mu \mathrm{g} / \mathrm{mL}$ & $55.89 \pm 13.21$ \\
\hline$a$ & $1 / \mathrm{h}$ & $4.92 \pm 1.59$ \\
\hline$a_{-} \mathrm{HL}$ & $\mathrm{H}$ & $0.16 \pm .08$ \\
\hline B & $\mu \mathrm{g} / \mathrm{mL}$ & $1.25 \pm .16$ \\
\hline$\beta$ & $1 / \mathrm{h}$ & $.25 \pm .04$ \\
\hline$\beta_{-} \mathrm{HL}$ & $\mathrm{H}$ & $2.77 \pm .40$ \\
\hline AUC & $\mu \mathrm{g} \cdot \mathrm{h} / \mathrm{mL}$ & $15.15 \pm 1.47$ \\
\hline AUMC & $\mu \mathrm{g} \cdot \mathrm{h}^{2} / \mathrm{mL}$ & $21.82 \pm 4.39$ \\
\hline$K_{12}$ & $1 / \mathrm{h}$ & $1.44 \pm .16$ \\
\hline$K_{21}$ & $1 / \mathrm{h}$ & $0.37 \pm .06$ \\
\hline MRT & $\mathrm{H}$ & $1.43 \pm .21$ \\
\hline $\mathrm{Vd}_{\mathrm{ss}}$ & $\mathrm{L} / \mathrm{kg}$ & $0.09 \pm .01$ \\
\hline CLB & L/h/kg & $0.06 \pm .01$ \\
\hline
\end{tabular}

$A$ and $B$ zero-time serum concentration intercepts of biphasic IV disposition curves, $a$ distribution rate constant, $\alpha \_$HL half-life of distribution, $\beta$ elimination rate constant, $\beta \mathrm{HL}$ half-life of elimination, $A U C$ area under the curve, $A U M C$ area under the first moment curve, $K_{12}$ and $K_{21}$ first-order transfer rate constants for drug distribution from the central compartment to the peripheral compartment and from the peripheral compartment to the central compartment, respectively, $M R T$ mean residence time, $V d_{s s}$ volume of distribution at steady-state, $C L B$ total body clearance

Table 4 Mean pharmacokinetic values ( \pm SD) of cefquinome after IM administration of $1 \mathrm{mg} / \mathrm{kg}$ in horses $(n=6)$ determined by high-performance liquid chromatography

\begin{tabular}{llc}
\hline Parameter & Unit & Mean \\
\hline$K_{01}$ & $1 / \mathrm{h}$ & $1.73 \pm .64$ \\
$K_{01 \_} \mathrm{HL}$ & $\mathrm{h}$ & $0.45 \pm .16$ \\
$K_{10}$ & $1 / \mathrm{h}$ & $0.16 \pm .03$ \\
$K_{10 \_} \mathrm{HL}$ & $\mathrm{h}$ & $4.39 \pm .79$ \\
$C_{\max }$ & $\mu \mathrm{g} / \mathrm{mL}$ & $0.73 \pm .08$ \\
$T_{\max }$ & $\mathrm{h}$ & $1.52 \pm .42$ \\
$\mathrm{AUC}$ & $\mu \mathrm{g} \cdot \mathrm{h} / \mathrm{mL}$ & $5.93 \pm .55$ \\
$\mathrm{~F}$ & $\%$ & $37.45 \pm 6.16$ \\
\hline
\end{tabular}

$K_{01}$ first-order absorption rate constant, $K_{01} \mathrm{HL}$ the half-life of absorption, $K_{10}$ first-order elimination rate constant, $K_{10-} \mathrm{HL}$ the half-life of elimination, $C_{\max }$ maximal serum concentration, $T_{\max }$ time taken to achieve maximal drug concentration, AUC area under the curve, $F$ absolute bioavailability

from the inhibitory sigmoid $E_{\max }$ model provided the ex vivo $\mathrm{AUC}_{24 \mathrm{~h}} / \mathrm{MIC}$ values required for various degrees of bacterial inhibition (Table 6). The relationship between the $\mathrm{AUC}_{24 \mathrm{~h}} / \mathrm{MIC}$ values and bacterial counts is presented in Figure 4. The calculated $\mathrm{AUC}_{24 \mathrm{~h}} / \mathrm{MIC}$ for serum that produces bacteriostatic $(E=0)$, bactericidal $(E=-3)$ and bacterial elimination activity $(E=-4)$ were $113.11,143.14$ and $159.16 \mathrm{~h}$, respectively. In addition, the $\% T>\mathrm{MIC}$ values based on the dose required for each bacterial inhibition effect were $147.17,153.34$ and $155.95 \%$ for $24-\mathrm{h}$ dosing intervals.

\section{Optimal dosage calculation}

The calculated dosages of cefquinome against S. equi for the bacteriostatic, bactericidal and bacterial elimination activity in this study were $0.38,0.48$ and $0.53 \mathrm{mg} / \mathrm{kg}$, respectively.

\section{Discussion}

The integration of the PK and PD indices are critical in estimating the efficacy and potency of a given drug, hence, are the basis for the selection of an applicable drug and to optimize dosage formulation [28]. The PK/ PD integration of cefquinome has been described previously in various animals $[12,17,18,21,29]$. In the present study, we investigated to optimize the dosage against strangles caused by Streptococcus equi subsp. equi, which is a common disease in horses.

The degree of serum protein binding cefquinome varies between animal species, and various studies have shown that cefquinome exhibited a relatively low degree of serum protein binding, ranging from approximately less than $5-17 \%[30,31]$. Consistently, we have shown in this study that cefquinome represented a markedly low degree of protein binding (3.91\%) in horse serum, which was similar to that in goats (11\%) and sheep (8.254$13.002 \%)[11,32,33]$.

The disposition of cefquinome following IV administration in horses was best described by a two-compartment open model, with a rapid distribution and elimination phase (Figure 2). Experiments performed in other animals after IV administration have led to similar conclusions, except for a few PK parameters. After IV administration of cefquinome, the elimination halflife $\left(t_{1 / 2 \beta}\right)$ of cefquinome in horses was $2.77 \mathrm{~h}$, which was similar to the elimination half-life in piglets $(1.85 \mathrm{~h})$, sows $(1.5-2.3 \mathrm{~h})$, while a little higher than black swans $(1.69 \mathrm{~h})$ and dogs $(0.85-0.98 \mathrm{~h})$ [15, 29, 34, 35]. Moreover, the $t_{1 / 2 \beta}$ value was similar to that obtained from horses after IV administration of cephalexin $(1.78 \mathrm{~h})$, cefepime $(2.1 \mathrm{~h})$ and ceftriaxone $(1.62 \mathrm{~h})$ [36-38]. These relatively short half-lives suggest that cefquinome, as a cephalosporin drug, is rapidly eliminated in horses. Moreover, to avoid stress and acquainted with animal welfare, we set the initial time-point for taking blood sample after IV administration $15 \mathrm{~min}$. According to the EPA guideline, the number of blood samples and the timing of sampling should be appropriate to allow adequate determination of absorption, distribution, and excretion [19, 20]. However, IV administration is considered to have a $100 \%$ 


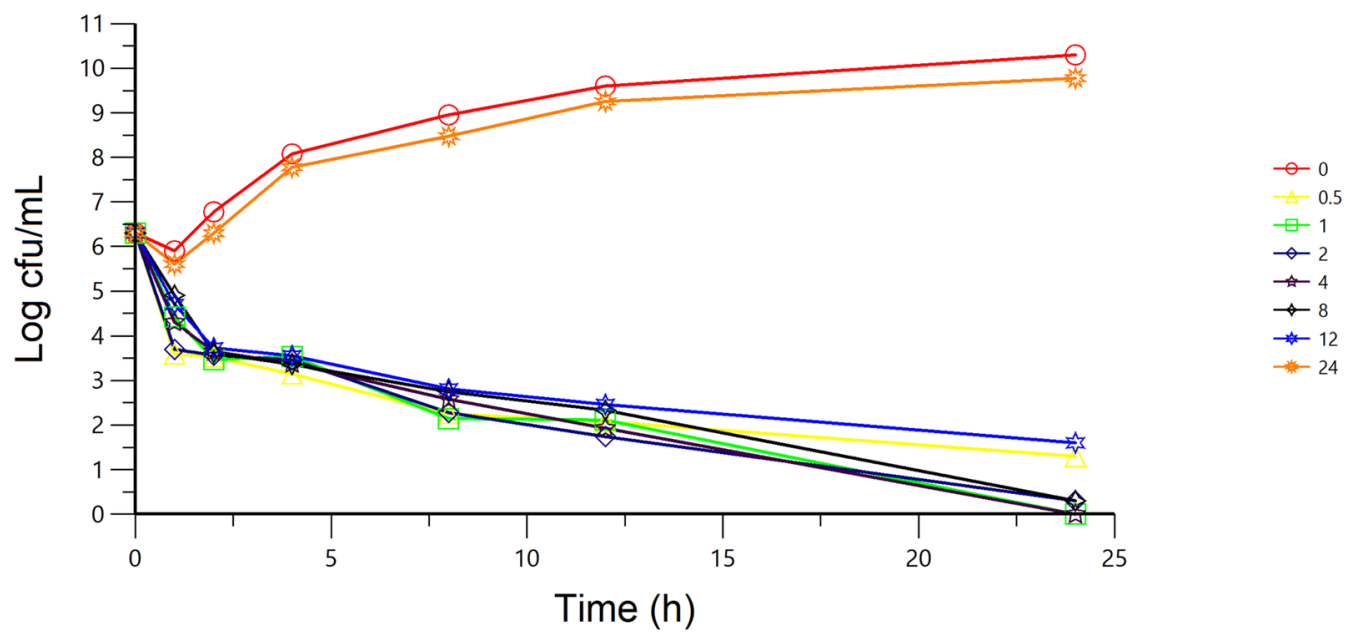

Figure 3 Ex vivo antibacterial activity of cefquinome against Streptococcus equi subsp. equi after IM administration to six horses at a dose of 1 mg/ $\mathrm{kg}$

Table 5 Ex vivo AUC $_{24 h} / M I C$ values of Streptococcus equi subsp. equi strain (mean $\pm S E M, n=6$ ) after IM administrations of cefquinome $(1 \mathrm{mg} / \mathrm{kg})$

\begin{tabular}{lll}
\hline Serum samples (h) & AUC $_{\mathbf{2 4 h}} \mathbf{h I C}(\mathbf{h})$ & $E(\log \mathbf{~ f u} / \mathbf{m L})$ \\
\hline 0 & 0 & 4.39 \\
.5 & $765 \pm 112.41$ & -5 \\
1 & $1277.5 \pm 145.12$ & -6.3 \\
2 & $1675 \pm 182.23$ & -6 \\
4 & $777.5 \pm 170.35$ & -6.3 \\
8 & $500 \pm 78.04$ & -6 \\
12 & $177.5 \pm 16.43$ & -4.69 \\
24 & $75 \pm 17.54$ & 3.48 \\
\hline
\end{tabular}

Table 6 Pharmacokinetic-pharmacodynamic integration of ex vivo data after IM administration of cefquinome (1 $\mathrm{mg} / \mathrm{kg}$ )

\begin{tabular}{ll}
\hline Parameter & Mean \\
\hline$E_{\max }(\log \mathrm{cfu} / \mathrm{mL})$ & 4.39 \\
$E_{0}(\log \mathrm{cfu} / \mathrm{mL})$ & -6.3 \\
$E_{\max }-E_{0}(\log \mathrm{cfu} / \mathrm{mL})$ & 10.69 \\
$E C_{50}(\log \mathrm{cfu} / \mathrm{mL})$ & 119.31 \\
$\mathrm{AUC}_{24 \mathrm{~h}} / \mathrm{MIC}$ for bacteriostatic activity (h) & 113.11 \\
$\mathrm{AUC}_{24 \mathrm{~h}} / \mathrm{MIC}$ for bactericidal activity (h) & 143.14 \\
$\mathrm{AUC}_{24 \mathrm{~h}} / \mathrm{MIC}$ for bacterial elimination (h) & 159.16 \\
Slope (N) & 5.02 \\
\hline
\end{tabular}

$E_{\text {max }}$ difference in number of bacteria (cfu/mL) in blank serum sample between time 0 and $24 \mathrm{~h} ; E_{0}$, difference in number of bacteria ( $\mathrm{cfu} / \mathrm{mL}$ ) in pooled serum samples between time 0 and $24 \mathrm{~h}$ when the detection limit $(20 \mathrm{cfu} / \mathrm{mL})$ is reached; $E C_{50}$, pharmacokinetic-pharmacodynamic parameter of drug that produced $50 \%$ of the maximal antibacterial effect; $A_{U C} C_{24 h} / M I C$, values required to achieve bacteriostatic, bactericidal and bacterial elimination activity; slope (N), the Hill coefficient that describes the steepness of the curve absorption, which is not affected by the absorption phase. Furthermore, this experiment is designed to obtain AUC at each time, which is the most important PK parameter to calculate the optimal dosage.

The AUC of cefquinome following a single IV administration was $15.15 \mu \mathrm{g} \mathrm{h} / \mathrm{mL}$ (1.47), which was higher than that reported in horses $(6.16 \mu \mathrm{g} \mathrm{h} / \mathrm{mL})$, but lower than that obtained from female goats $(43.57 \mu \mathrm{g} \mathrm{h} / \mathrm{mL})$ [14, 21]. The result was similar to the AUC obtained after IV administration of ceftiofur in foals $(17.62 \mu \mathrm{g} \mathrm{h} / \mathrm{mL})$ but varies from horses $(9.33 \mu \mathrm{g} \mathrm{h} / \mathrm{mL})$ [39]. Such differences are common and could be related to interspecies variation, assay methods, age, breed, dose and the drug formulation used.

The volume of distribution $\left(\mathrm{Vd}_{\mathrm{ss}}\right)$ indicates the diffusion of the drug in the body tissue. The $\mathrm{Vd}_{\mathrm{ss}}$ of cefquinome in horses in this study was $0.09 \mathrm{~L} / \mathrm{kg}$. The $\mathrm{Vd}_{\mathrm{ss}}$ value obtained from the current study was slightly lower than with those obtained from cephalexin $(0.29 \mathrm{~L} / \mathrm{kg})$ and ceftriaxone $(0.33 \mathrm{~L} / \mathrm{kg})$ in horses $[36,37]$. Experimental investigations in other animals after IV administration of cefquinome have led to a similar conclusion, with values of $0.46 \mathrm{~L} / \mathrm{kg}$ in piglets and $0.23 \mathrm{~L} / \mathrm{kg}$ in calves, revealing that the $\mathrm{Vd}_{\mathrm{ss}}$ of the cefquinome in the body is very small $[29,34]$. The major reason for the low $\mathrm{Vd}_{\mathrm{ss}}$ value appears to be the less hydrophobic nature of cefquinome, low fatsolubility and its low pKa value of 2.51-2.91, which effectively confines cefquinome to the extracellular fluid space [32].

In the present study, the disposition of cefquinome following $1 \mathrm{mg} / \mathrm{kg}$ of IM administration in horses was described by a one-compartment open model, which was similar to that described in buffalo, goat and camel [10, $12,14]$. However, the result disagreed with that reported 

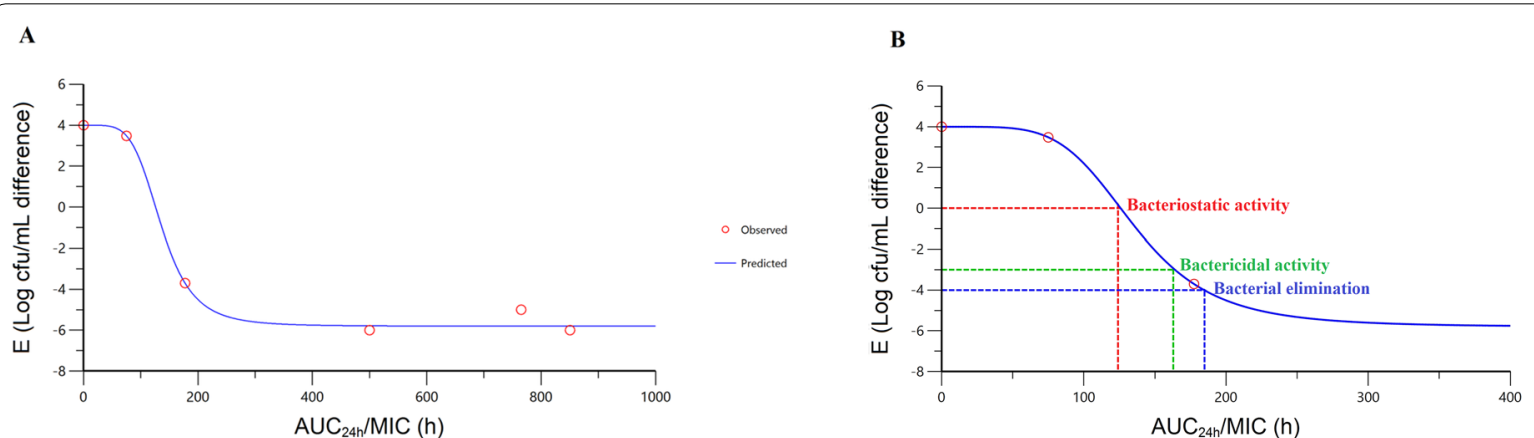

Figure 4 Sigmoidal $E_{\max }$ relationship for ex vivo $\mathrm{AUC}_{24 \mathrm{~h}} / \mathrm{MIC}$ for Streptococcus equi subsp. equi in horse serum samples versus bacterial count (log cfu/mL difference). The curve represents the line of predicted values from the inhibitory sigmoid $E_{\max }$ equation, and the circles are the mean observed values

previously in sheep, and chickens that administered cefquinome IM at a dose of $2 \mathrm{mg} / \mathrm{kg}$ in which the dispositions were described by two-compartment open models $[5,40]$.

After IM administration of cefquinome in horses, the elimination half-life of cefquinome was $4.39 \mathrm{~h}$ (0.79), which was similar to that in sheep $(4.47 \mathrm{~h})$, buffalos $(3.73 \mathrm{~h})$ and horses $(3.15 \mathrm{~h})$ following IM administration of $2.2 \mathrm{mg} / \mathrm{kg}$ ceftiofur [11, 12, 41]. Cefquinome showed long elimination half-life after IM injection in sheep, goats, buffalo calves, cattle calves, and cows. Horses that received cefquinome at $1 \mathrm{mg} / \mathrm{kg}$ also showed a relatively longer $t_{1 / 2 \beta}$ than those received $6 \mathrm{mg} / \mathrm{kg}$ [21]. Such differences are common and frequently related to interspecies variation, assay methods used, the formulation of the drug, and detection methods used [42].

In this study, the maximum serum concentration of cefquinome $\left(C_{\max }\right)$ was $0.73 \mu \mathrm{g} / \mathrm{mL}$. The result was similar to the $C_{\max }$ obtained from 1-month-old sheep $(0.732 \mu \mathrm{g} / \mathrm{mL})$ given IM administration of $1 \mathrm{mg} / \mathrm{kg}$ of cefquinome, and horses $(0.885 \mu \mathrm{g} / \mathrm{mL})$ following a single IM administration of $6.6 \mathrm{mg} / \mathrm{kg}$ ceftiofur crystalline-free acid $[11,43]$. However, the result was lower than that obtained from horses after IV infusion of cefquinome $(5.14 \mu \mathrm{g} / \mathrm{mL})$ and IM administration of ceftiofur sodium in horses $(4.49 \mu \mathrm{g} / \mathrm{mL})[21,44]$. The time taken to achieve maximum serum concentration $\left(T_{\max }\right)$ was $1.52 \mathrm{~h}$, which was shorter than the $T_{\max }$ recorded in sheep $(2.61 \mathrm{~h})$ and goats $(2.62 \mathrm{~h})$ [42]. These variations might be attributed to anatomical differences between species, health status, and drug formulations in each case.

The systemic bioavailability $(F)$ following IM administration of cefquinome was calculated to be $37.45 \%$, which was noticeably smaller when compared with $89.31 \%$ in sheep, $86.30 \%$ in buffalo calves and $74.2 \%$ in black swans $[5,12,35]$. The low systemic bioavailability value of cefquinome in this study might be attributed to decreased absorption of the drug from the site of injection, low water solubility of the drug formulation, dispersion of the injected solution, and decreased blood flow at the muscle site $[45,46]$. However, to overcome this problem, further studies on IM injections formulation is recommended.

The MIC of cefquinome against S. equi (ATCC 39,506) was $0.016 \mu \mathrm{g} / \mathrm{mL}$ in this study, which was consistent with the MIC against $S$. equi strains isolated from nine horses that ranged from 0.008 to $0.063 \mu \mathrm{g} / \mathrm{mL}$ [2].

The best PK/PD measures to describe the efficacy of time-dependent antibiotics is the time during which the drug concentration exceeds the MIC (\%T $>$ MIC). Cefquinome is a $\beta$-lactam antibiotic and so shows the timekilling characteristic, which means that $\% T>M I C$ is an essential parameter to describe the antibacterial activity. However, the AUC/MIC can also be considered as a better PK/PD index for $\beta$-lactams with long elimination halflife [47]. In general, though cefquinome has regarded as having short elimination half-life, it also shows long elimination half-life after intramuscular injection in sheep, goats, buffalo calves, cattle calves, and cows. Horses that received cefquinome at $1 \mathrm{mg} / \mathrm{kg}$ also showed a relatively long elimination half-life than those received $6 \mathrm{mg} /$ $\mathrm{kg}$ [21]. Furthermore, Yu et al. argued that the different values of $\% T>$ MIC versus bacterial count $(\log \mathrm{cfu} / \mathrm{mL})$ could not be obtained in ex vivo PK/PD integration, and the AUIC exerts a considerable influence on the treatment effectiveness of cefquinome [13, 18]. Such differences are common and frequently related to interspecies variation, assay methods used, and the formulation of the drug used [42].

In this study, the ex vivo $\mathrm{AUC}_{24 \mathrm{~h}} / \mathrm{MIC}$ parameters were calculated, and the data was integrated by the inhibitory sigmoid $E_{\max }$ model with the differences between bacterial counts $(\log \mathrm{cfu} / \mathrm{mL})$ after $24 \mathrm{~h}$ of incubation. The $\mathrm{AUC}_{24 \mathrm{~h}} / \mathrm{MIC}$ required for bacteriostatic, bactericidal 
and bacterial elimination activity were determined in the serum and the optimal dose required to each effect compartment were $0.38,0.48$ and $0.53 \mathrm{mg} / \mathrm{kg}$, respectively. However, these estimations did not consider factors, such as the host immune system and pathological changes during infection. In order to overcome these limitations, it would be necessary to consider estimates of PK parameters and MIC obtained from pathogenic species to accommodate the potential needs of the entire patient population [22].

In order to evaluate the optimal daily dosage obtained from the current study, the equation from previous reports, in addition to the current data regarding the PK parameters of cefquinome, were used [48]. Considering the average serum cefquinome concentrations during the three consecutive dosing intervals (Figure 5), PK parameters were applied to calculate the daily IM dosage based on the following equation: and $\mathrm{PK} / \mathrm{PD}$ integration can be applied to overcome this limitation.

\section{Conclusions}

This study is the first to use PK/PD modelling as a strategy for calculating the optimal dosage regimens of cefquinome against $S$. equi, the causative agent of strangles in equine species. The result suggests that the experimental dose administered either by IV or IM at a dosage of $1 \mathrm{mg} / \mathrm{kg}$ in horses is enough to exceed the MIC $(\mathrm{MIC}=0.016 \mu \mathrm{g} / \mathrm{mL})$ for up to $12 \mathrm{~h}$ in serum and that dosage of $0.53 \mathrm{mg} / \mathrm{kg}$ every $24 \mathrm{~h}$ could produce bacterial elimination activity. However, in this study we only used the Hill equation to determine the dosage using single values instead of using the Monte-Carlo simulations due to lack of sufficient MIC data range of cefquinome against $S$. equi subsp. equi in horses. Hence, there is a need to extend the current study by validating the calcu-

IM dose of cefquinome $=\left[\left(C_{(\text {average })} \times \mathrm{Vd}_{\mathrm{ss}} \times 24 \mathrm{~h} / 1.44\right)\right] / T_{1 / 2 \beta}$

Accordingly, the calculated IM dosage was $0.175 \mathrm{mg} /$ $\mathrm{kg}$, which was three-fold lower than the dosage required to eliminate $S$. equi strain in this study. The reason it is different from the recommended dosage might be that the dosage regimens only based on PK parameters have limitations to reflect the characteristic differences of various strains, and the combination of PD parameters lated dosage in clinical circumstances to confirm its therapeutic efficacy.

\section{Ethics approval and consent for publication}

All research protocols and animal experiments in this study were reviewed and approved by the Institutional Animal Care and Use Committee (IACUC) in Gyeongsangbuk-do, Republic of Korea (Gyeongbuk IACUC-81).

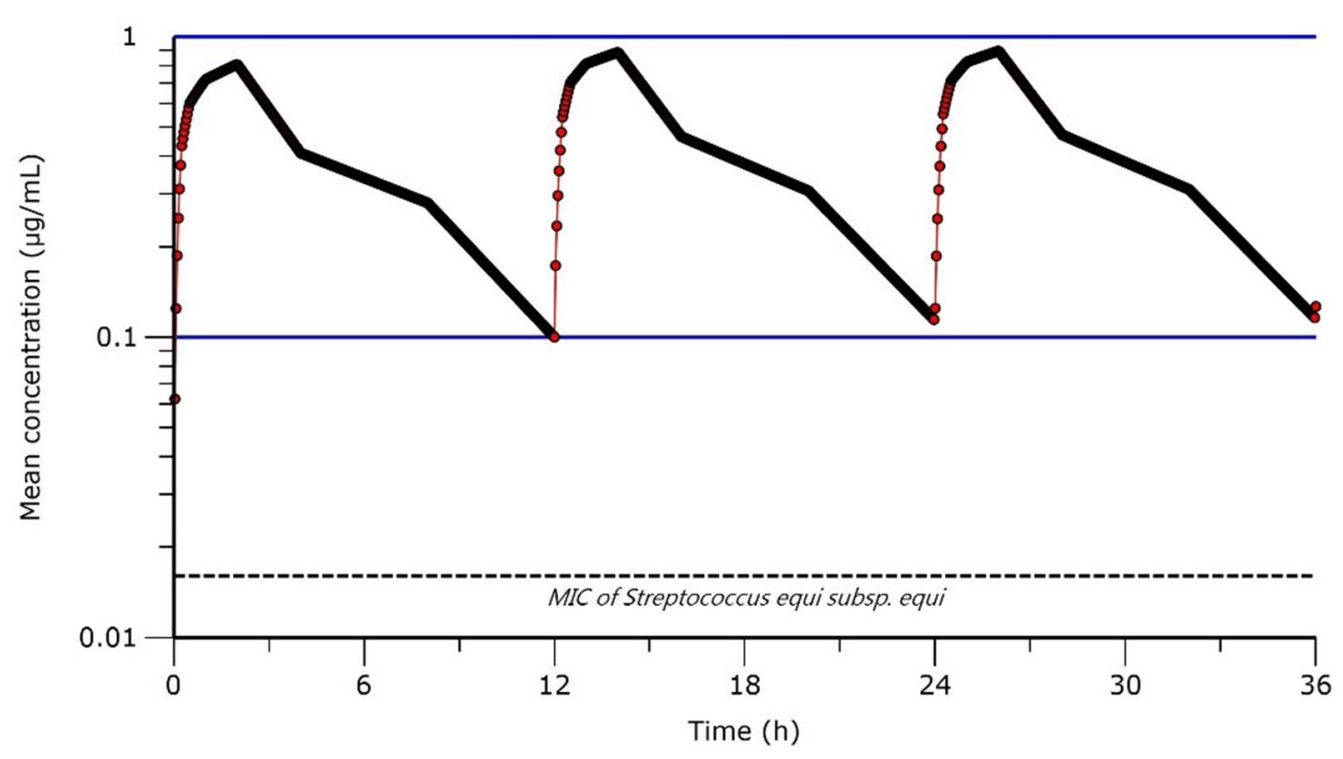

Figure 5 Simulated semi-logarithmic graph depicting the time versus cefquinome concentration in serum after repeated IM administration of the drug at a dose of $1 \mathrm{mg} / \mathrm{kg}$ every $12 \mathrm{~h}$ for three consecutive intervals. The indicated MIC of cefquinome against S. equi subsp. equi is $2 \mu \mathrm{g} / \mathrm{mL}$ 


\section{Competing interests}

\section{The authors declare there is no conflict of interest.}

\section{Supplementary information}

Supplementary information accompanies this paper at https://doi. org/10.1186/s13567-020-00853-2.

Additional file 1. Serum protein binding percentage (\%) of cefquinome in six horses.

Additional file 2. Calibration curves of cefquinome determined by highperformance liquid chromatography.

\section{Abbreviations}

AUC: area Under the Curve; CFU: colony Forming Unit; CLB: total body clearance; $C_{\max }$ : maximum concentration; $E_{\max }$ : maximum effect; $F$ : bioavailability; HPLC: high-performance liquid chromatography; IM: intramuscular; IV: intravenous; KCCM: Korea Culture Centre of Microorganisms; LB: Luria-Bertani; MIC: minimum inhibitory concentration; MRT: mean residence time; PD: pharmacodynamics; PK: pharmacokinetics; TSB: tryptic soy blood; $\mathrm{Vd}_{s \mathrm{~s}}$ : volume of distribution at steady state.

\section{Acknowledgments}

Not applicable.

\section{Authors' contribution}

DHL involved in, design, acquisition of data, analysis, and drafting the manuscript; BTB involved in some of the experiments, analyzing the data, and critically revising the manuscript; EBL, SJL and NB involved in some of the experiments and reviewed the manuscript; YSP and SCP conceived the study, analyzed the data and approved the final version of the manuscript. All authors read and approved the final manuscript.

\section{Funding}

This research is funded in part by the National Research Foundation of Korea (NRF) through the Ministry of Education (2019R1A2C2006277) and in part by a grant (Z-1543081-2020-22-02) from the Animal and Plant Quarantine Agency, Ministry of Agriculture, Food and Rural Affairs, Republic of Korea. The funders had no role in study design, data collection and interpretation, or the decision to submit the work for publication. The manuscript was based, in part, on the first author's master dissertation at Kyungpook National University.

\section{Availability of data and materials}

The dataset(s) supporting the conclusions of this article is(are) included within the article.

\section{Author details}

1 Laboratory of Veterinary Pharmacokinetics and Pharmacodynamics, College of Veterinary Medicine, Kyungpook National University, Bukgu, Daegu 41566 Republic of Korea. ${ }^{2}$ Developmental and Reproductive Toxicology Research Group, Korean Institute of Toxicology, Daejeon 34114, Republic of Korea. ${ }^{3}$ Department of Equine Industry, Korea National College of Agriculture and Fisheries, Jeonju 54874, Republic of Korea.

\section{Received: 20 May 2020 Accepted: 22 September 2020}

Published online: 15 October 2020

\section{References}

1. Guérin-Faublée V, Carret G, Houffschmitt P (2003) In vitro activity of 10 antimicrobial agents against bacteria isolated from cows with clinical mastitis. Vet Rec 152:466-471. https://doi.org/10.1136/vr.152.15.466

2. Thomas E, Thomas V, Wilhelm C (2006) Antibacterial activity of cefquinome against equine bacterial pathogens. Vet Microbiol 115:140-147. https://doi.org/10.1016/j.vetmic.2005.12.019

3. CVMP_Diclofenac_Summary_Report (2003) Committee for Veterinary Medicinal Products. Diclofenac Summary Report. European Agency for the Evaluation of Medicinal Products Veterinary Medicines and Inspections, London. pp 1-9

4. Shpigel NY, Levin D, Winkler M et al (1997) Efficacy of cefquinome for treatment of cows with mastitis experimentally induced using Escherichia coli. J Dairy Sci 80:318-323. https://doi.org/10.3168/jds.S0022 -0302(97)75941-1

5. Uney K, Altan F, Elmas M (2011) Development and validation of a high-performance liquid chromatography method for determination of cefquinome concentrations in sheep plasma and its application to pharmacokinetic studies. Antimicrob Agents Chemother 55:854-859. https:// doi.org/10.1128/AAC.01126-10

6. Quinn PJ, Markey B, Leonard F et al (2011) Veterinary microbiology and microbial disease, 2nd edn. Wiley-Blackwell, Oxford

7. Boyle AG, Timoney JF, Newton JR et al (2018) Streptococcus equi infections in horses: guidelines for treatment, control, and prevention of strangles_revised consensus statement. J Vet Intern Med 32:633-647. https://doi.org/10.1111/jvim.15043

8. Salmon SA, Watts JL, Yancey RJ (1996) In vitro activity of Ceftiofur and its primary metabolite, desfuroylceftiofur, against organisms of veterinary importance. J Vet Diagn Invest 8:332-336. https://doi.org/10.1177/10406 3879600800309

9. Seady M, Atwa S, Beskawy M et al (2018) Clinical, molecular diagnosis and antimicrobial sensitivity of streptococcus Equi causing strangles. Alex J Vet Sci 56:78. https://doi.org/10.5455/ajvs.288463

10. Al-Taher AY (2010) Pharinacokinetics of Cefquinome in camels. J Anim Vet Adv 9:848-852. https://doi.org/10.3923/javaa.2010.848.852

11. Tohamy MA (2011) Age-related intramuscular pharmacokinetics of cefquinome in sheep. Small Rumin Res 99:72-76. https://doi. org/10.1016/j.smallrumres.2011.03.004

12. Venkatachalam D, Dumka VK, Ranjan B (2018) Pharmacokinetics of a single intramuscular injection of cefquinome in buffalo calves. J Vet Pharmacol Ther 41:155-158. https://doi.org/10.1111/jvp.12451

13. Yu Y, Zhou YF, Chen MR et al (2016) In vivo pharmacokinetics/pharmacodynamics of cefquinome in an experimental mouse model of Staphylococcus aureus mastitis following intramammary infusion. PLoS One 11:e0156273. https://doi.org/10.1371/journal.pone.0156273

14. Sagar R, Sultana M, Dumka V et al (2015) Pharmacokinetics and dosage regimen of cefquinome in healthy female goats following intravenous administration. J Vet Pharmacol Toxicol 14:74-78

15. Corum O, Corum DD, Er A, Uney K (2019) Pharmacokinetics of cefquinome after single and repeated subcutaneous administrations in sheep. $J$ Vet Pharmacol Ther 42:647-653. https://doi.org/10.1111/jvp.12750

16. Wen X, Gehring R, Stallbaumer A et al (2016) Limitations of MIC as sole metric of pharmacodynamic response across the range of antimicrobial susceptibilities within a single bacterial species. Sci Rep 6:1-8. https://doi. org/10.1038/srep37907

17. Ahmad I, Hui YZ (2015) Integration of PK/PD for dose optimization of Cefquinome against Staphylococcus aureus causing septicemia in cattle. Front Microbiol. https://doi.org/10.3389/fmicb.2015.00588

18. Zhang BX, Lu XX, Gu XY et al (2014) Pharmacokinetics and ex vivo pharmacodynamics of cefquinome in porcine serum and tissue cage fluids. Vet J 199:399-405. https://doi.org/10.1016/j.tvjl.2013.12.015

19. CVMP (2017) Draft guideline on conduct of pharmacokinetic studies in target animal species-EMEA/CVMP/EWP/133/1999-Rev.1. London

20. Park S-C, Yun H-I (2003) Clinical pharmacokinetics of norfloxacin-glycine acetate after intravenous and intramuscular administration to horses. Res Vet Sci 74:79-83. https://doi.org/10.1016/s0034-5288(02)00150-9

21. Uney K, Altan F, Altan S et al (2017) Plasma and synovial fluid pharmacokinetics of cefquinome following the administration of multiple doses in horses. J Vet Pharmacol Ther 40:239-247. https://doi.org/10.1111/ jvp. 12362

22. Elias G, Lee JS, Hwang MH et al (2009) Pharmacokinetics and pharmacokinetic/pharmacodynamic integration of orbifloxacin in Korean Hanwoo cattle. J Vet Pharmacol Ther 32:219-228. https://doi.org/10.111 1/j.1365-2885.2008.01027.x

23. Craig A, Suh B (1991) Protein binding and the antibacterial effects. In: Lorain V (ed) Antibiotics in laboratory medicine, third. Lippincott Williams \&Wilkins, Philadelphia, pp 367-402

24. Yamaoka K, Nakagawa T, Uno T (1978) Application of Akaike's information criterion (AIC) in the evaluation of linear pharmacokinetic equations. 
J Pharmacokinet Biopharm 6:165-175. https://doi.org/10.1007/BF011 17450

25. CLSI (2017) M100-S23 Performance Standards for Antimicrobial Susceptibility Testing; Twenty-Third Informational Supplement An informational supplement for global application developed through the Clinical and Laboratory Standards Institute consensus process, 27th edn. Clinical and Laboratory Standards Institute, Wayne

26. Aliabadi FS, Lees P (2003) Pharmacokinetic-pharmacodynamic integration of danofloxacin in the calf. Res Vet Sci 74:247-259. https://doi. org/10.1016/50034-5288(03)00005-5

27. Turnidge JD (1998) The pharmacodynamics of $\beta$-lactams. Clin Infect Dis 27:10-22. https://doi.org/10.1086/514622

28. Birhanu BT, Lee E-B, Park S-C (2020) Evaluation of the pharmacokineticpharmacodynamic integration of marbofloxacin in combination with methyl gallate against Salmonella typhimurium in rats. PLoS One 15:e0234211. https://doi.org/10.1371/journal.pone.0234211

29. Limbert M, Isert D, Klesel $\mathrm{N}$ et al (1991) Antibacterial activities in vitro and in vivo and pharmacokinetics of cefquinome (HR 111V), a new broadspectrum cephalosporin. Antimicrob Agents Chemother 35:14-19. https ://doi.org/10.1128/AAC.35.1.14

30. Wang J, Shan Q, Ding H et al (2014) Pharmacodynamics of cefquinome in a neutropenic mouse thigh model of staphylococcus aureus infection. Antimicrob Agents Chemother 58:3008-3012. https://doi.org/10.1128/ AAC.01666-13

31. Zhang L, Yao L, Kang Z et al (2019) Microdialysis determination of cefquinome pharmacokinetics in murine thigh from healthy, neutropenic, and Actinobacillus pleuropneumoniae-infected mice. Front Pharmacol 10:249. https://doi.org/10.3389/fphar.2019.00249

32. El Badawy SA, Amer AM, Kamel GM et al (2015) Comparative pharmacokinetics using a microbiological assay and high performance liquid chromatography following intravenous administration of cefquinome in lactating goats with and without experimentally induced Staphylococcus aureus mastitis. Small Rumin Res 133:67-76. https://doi.org/10.1016/j. smallrumres.2015.11.004

33. Sams RA, RuoffWW (1985) Pharmacokinetics and bioavailability of cefazolin in horses. Am J Vet Res 46:348-352

34. Li XB, Wu WX, Su D et al (2008) Pharmacokinetics and bioavailability of cefquinome in healthy piglets. J Vet Pharmacol Ther 31:523-527. https:// doi.org/10.1111/j.1365-2885.2008.00989.x

35. Zhao DH, Wang XF, Wang Q, Li LD (2017) Pharmacokinetics, bioavailability and dose assessment of Cefquinome against Escherichia coli in black swans (Cygnus atratus). BMC Vet Res 13:226. https://doi.org/10.1186/ s12917-017-1148-7

36. Villa R, Belloli C, Cagnardi P et al (2002) Pharmacokinetics of cephalexin in the horse after intravenous and intramuscular administration of two formulations. Vet J 164:74-76. https://doi.org/10.1053/tvjl.2001.0666
37. Ringger NC, Pearson EG, Gronwall R, Kohlepp SJ (1996) Pharmacokinetics of ceftriaxone in healthy horses. Equine Vet J 28:476-479. https://doi. org/10.1111/j.2042-3306.1996.tb01620.x

38. Guglick MA, MacAllister CG, Clarke CR et al (1998) Pharmacokinetics of cefepime and comparison with those of ceftiofur in horses. Am J Vet Res 59:458-463

39. Wilson WD, Mihalyi JE (1998) Comparative pharmacokinetics of ceftiofur in neonatal foals and adult horses. In: Neonatal Septicemia Workshop II. Davis, $\mathrm{p} 1$

40. ElSayed M, ElKomy A, Elbarawy A, Ibrahim D (2015) Pharmacokinetics and tissue residues of ceftiofur in normal and Escherichia coli infected chickens. J Physiol Pharmacol Adv 5:574. https://doi.org/10.5455/jppa.20141 203095345

41. Jaglan PS, Roof RD, Yein FS et al (1994) Concentration of ceftiofur metabolites in the plasma and lungs of horses following intramuscular treatment. J Vet Pharmacol Ther 17:24-30. https://doi. org/10.1111/j.1365-2885.1994.tb00517.x

42. El-Hewaity M, Abd El Latif A, Soliman A, Aboubakr M (2014) Comparative pharmacokinetics of cefquinome (Cobactan 2.5\%) following repeated intramuscular administrations in sheep and goats. J Vet Med 2014:949642. https://doi.org/10.1155/2014/949642

43. Collard WT, Cox SR, Lesman SP et al (2011) Pharmacokinetics of ceftiofur crystalline-free acid sterile suspension in the equine. J Vet Pharmacol Ther 34:476-481. https://doi.org/10.1111/j.1365-2885.2011.01266.x

44. Fultz L, Giguère $S$, Berghaus $L$ et al (2015) Pulmonary pharmacokinetics of desfuroylceftiofur acetamide after nebulisation or intramuscular administration of ceftiofur sodium to weanling foals. Equine Vet J 47:473-477. https://doi.org/10.1111/evj.12316

45. Tuttle CB (1977) Intramuscular injections and bioavailability. Am J Hosp Pharm 34:965-968

46. Takahashi H, Ogata H, Warabioka R et al (1990) Decreased absorption as a possible cause for the lower bioavailability of a sustained-release propranolol. J Pharm Sci 79:212-215. https://doi.org/10.1002/jps.26007 90306

47. Toutain P-L, Bousquet-Mélou A, Damborg P et al (2017) En route towards European clinical breakpoints for veterinary antimicrobial susceptibility testing: a position paper explaining the VetCAST approach. Front Microbiol 8:2344. https://doi.org/10.3389/fmicb.2017.02344

48. Mechesso AF, Lee SJ, Park NH, Park SC (2018) Pharmacokinetic parameters and optimal dosage of a florfenicol and tylosin mixture in beagle dogs. Vet Med 63:329-334. https://doi.org/10.17221/165/2017-VETMED

\section{Publisher's Note}

Springer Nature remains neutral with regard to jurisdictional claims in published maps and institutional affiliations.
Ready to submit your research? Choose BMC and benefit from:

- fast, convenient online submission

- thorough peer review by experienced researchers in your field

- rapid publication on acceptance

- support for research data, including large and complex data types

- gold Open Access which fosters wider collaboration and increased citations

- maximum visibility for your research: over $100 \mathrm{M}$ website views per year

At BMC, research is always in progress.

Learn more biomedcentral.com/submissions 